\title{
Assessment of Boron Application in Chestnuts: Nut Yield and Quality
}

\section{Ester Portela, Jorge Ferreira-Cardoso, José Louzada \& José Gomes-Laranjo}

To cite this article: Ester Portela, Jorge Ferreira-Cardoso, José Louzada \& José Gomes-Laranjo (2015) Assessment of Boron Application in Chestnuts: Nut Yield and Quality, Journal of Plant Nutrition, 38:7, 973-987, DOI: 10.1080/01904167.2014.963116

To link to this article: http://dx.doi.org/10.1080/01904167.2014.963116

Accepted author version posted online: 25

Sep 2014.

Published online: 25 Sep 2014.

Submit your article to this journal $₫$

Џ Article views: 147

Q View related articles $\sqsubset$

View Crossmark data ¿ 


\title{
ASSESSMENT OF BORON APPLICATION IN CHESTNUTS: NUT YIELD AND QUALITY
}

\author{
Ester Portela, ${ }^{1}$ Jorge Ferreira-Cardoso, ${ }^{1}$ José Louzada, ${ }^{2}$ \\ and José Gomes-Laranjo'
}

${ }^{1}$ Department of Biological and Environmental Engineering, Center for Research and Technology of Agro-Environment and Biological Sciences - CITAB, University of

Trás-os-Montes and Alto Douro, Vila Real, Portugal

${ }^{2}$ Department of Forest Sciences and Landscape Architecture, Center for Research and Technology of Agro-Environment and Biological Sciences - CITAB, University of Trás-os-Montes and Alto Douro, Vila Real, Portugal

$\square \quad$ A field trial was conducted between 2006 and 2009 in order to quantify the effect of boron (B) application on the yield and quality of chestnuts. The trial was established in an acid soil derived from siliceous schist and two levels of B were applied. Fruit abortion and nut yield per tree were measured, and nut quality parameters and chemical composition of the kernel were determined. Foliar B concentration was $8.6 \mathrm{mg} \mathrm{kg}^{-1}$ in the control trees and $48.4 \mathrm{mg} \mathrm{kg}^{-1}$ in fertilized chestnuts. Boron improved fruit setting and promoted nut production by $77 \%$. In 2008, the occurrence of cold temperatures enhanced the effect of B on fruit setting, which was four-fold, whereas with the normal temperatures of 2009 the increase was lower. The drought of 2009 was responsible for the ruinous chestnut caliber and shell cracking. Boron induced a significant increase in the crude fat of chestnut kernel.

Keywords: Castanea sativa, nut quality, fruit setting, fruit abortion, proximate composition, crude fat, soil boron

\section{INTRODUCTION}

The compilation of boron (B) concentration in leaves of chestnut (Castanea sativa Mill.) conducted over a decade (1996-2006) in the northeastern region of Portugal (NE region) showed that this micronutrient is often in short supply in many orchards. There is increasing evidence that many

Received 4 July 2012; accepted 19 May 2013.

Address correspondence to E. Portela, Department of Biological and Environmental Engineering, Center for Research and Technology of Agro-Environment and Biological Sciences - CITAB, University of Trás-os-Montes and Alto Douro, Ap1013, 5000-801 Vila Real, Portugal. E-mail: eportela@utad.pt 
orchards are managed under hidden hunger, which limits nut production. Several surveys for assessment of nutrient status of chestnut have revealed that foliar B concentrations of many orchards were lower than $20 \mathrm{mg} \mathrm{kg}^{-1}$, the value of B concentration tentatively regarded as critical (Portela et al., 2007). The conspicuousness of B deficiency varies a great deal from year to year. For this reason, a long-term evaluation of B application is needed, since climatic conditions clearly affect the incidence and the severity of the deficiency. According to Shorrocks (1997) and Huang et al. (2005), both temperature and rainfall influence may exacerbate B deficiency and crop response to B application. The recent work of Pereira et al. (2011), carried out in NE region, also emphasizes the impact of temperature and precipitation on chestnut productivity and nut quality and on the chemical composition of the kernel (Ferreira-Cardoso, 2007).

Portela et al. (2011) describe B deficiency symptoms in chestnut, and show that B disorders affect both fruit setting and chestnut production. However, systematic post-treatment evaluations have not yet been carried out. Thus, the objective of the present study, conducted in a chestnut orchard over three years, was to quantify the effect of B application, on nut yield and on several parameters of nut quality. In addition, the output of $\mathrm{B}$ due to nut export was also determined. The outputs of other macro and micronutrients already exist (Pires and Portela, 2009), but there is no data available to calculate the removal of B by fruit harvest. These results may supply additional and useful data for correction measures in chestnut orchards.

\section{MATERIALS AND METHODS}

\section{Site Characterization}

The experiment was carried out in Jou ( $41^{\circ} 28^{\prime} 35^{\prime \prime} \mathrm{N}$ and $\left.7^{\circ} 25^{\prime} 17^{\prime \prime} \mathrm{W}\right)$ at $620 \mathrm{~m}$ a.s.l. with undulating topography (5-8\% slope). The chestnut orchard is established on well-drained and shallow soils $(25-40 \mathrm{~cm}$ depth) derived from quartzophyllites. Soil classification varies from Haplic Dystric Leptosol to Leptic Dystric Cambisol (FAO, 2006). The soils are loam (13\% clay) with abundant stone fragments at the surface and about $35 \%$ (v) gravel up to $40 \mathrm{~cm}$; they have $26 \mathrm{~g} \mathrm{~kg}^{-1}$ organic matter and they are quite acid with $\mathrm{pH}$ in water $\left(\mathrm{H}_{2} \mathrm{O}\right)<5$. The extractable $\mathrm{B}$ exhibits some variation $(0.34-0.63 \mathrm{mg}$ $\mathrm{kg}^{-1}$ ) throughout the orchard. The detailed chemical properties of the soil have been presented elsewhere (Portela et al., 2011).

\section{Climatic Data}

The average monthly temperatures and rainfall from April 2007 to October 2009 are indicated in Table 1. Mean annual values of precipitation and 


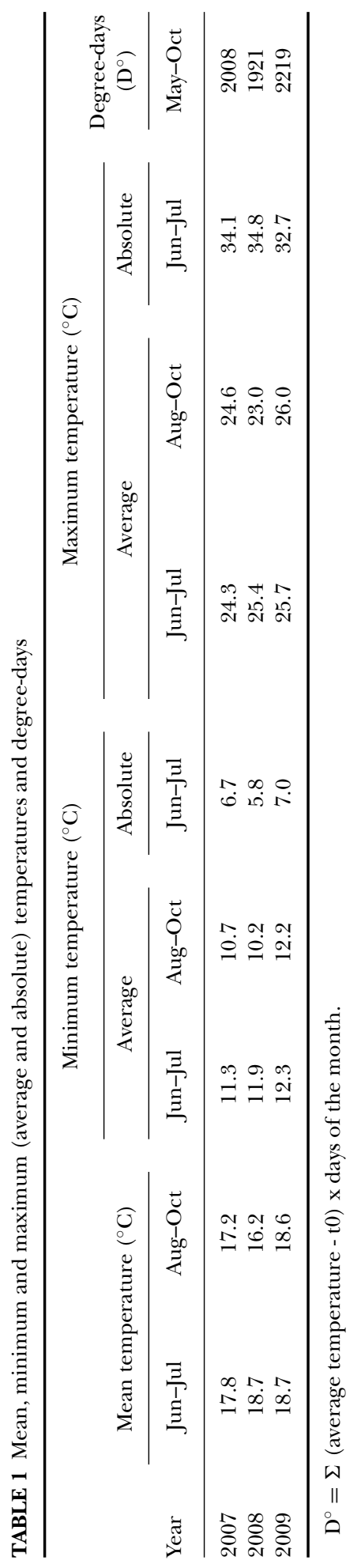


TABLE 2 Precipitation (mm) from November to October (2006-2009)

\begin{tabular}{|c|c|c|c|c|}
\hline Months & 2006-20007 & 2007-2008 & 2008-2009 & $\begin{array}{l}\text { Average of } \\
30 \text { years }+\end{array}$ \\
\hline$\sum_{(\text {November-March })}$ & 661 & 409 & 566 & 754 \\
\hline April & 37 & 212 & 70 & 77 \\
\hline May & 73 & 103 & 22 & 69 \\
\hline June & 74 & 14 & 46 & 48 \\
\hline July & 33 & 2 & 31 & 14 \\
\hline August & 27 & 13 & 20 & 17 \\
\hline September & 44 & 49 & 1 & 49 \\
\hline October & 23 & 47 & 159 & 100 \\
\hline$\sum_{\text {(April-September) }}$ & 288 & 393 & 190 & 273 \\
\hline$\sum$ Year & 972 & 849 & 856 & 1128 \\
\hline
\end{tabular}

* November 2006-October 2007 and so forth; + according to INMG (1991).

temperature over the last 30 years were $1079 \mathrm{~mm}$ and $13.3^{\circ} \mathrm{C}$, respectively (INMG, 1991).

Table 1 summarizes temperature parameters such as minimum and maximum temperatures, absolute minimum and maximum values, and degreedays. Degree-days provide a measure of growth rate and crop phenology on the basis of the accumulation of growing degree-days, as proposed by Cesaraccio et al. (2001). Degree-days were calculated from leaf emergence to fruit leaf fall, using the formula $\sum$ temperature $\left({ }^{\circ} \mathrm{D}\right)=\left(\mathrm{T} \chi-\mathrm{t}_{0}\right) \times n$ : where ' $\chi$ ' is the average temperature each month, $\mathrm{t}_{0}$ the base temperature, which is $6^{\circ} \mathrm{C}$ for chestnut (Dinis et al, 2011a), and ' $n$ ' total days of each month. Precipitation per month is also shown from leaf emergence (April) to fruit fall (October), while total rainfall over the year is shown in Table 2, as are also the mean values of the previous 30 years.

\section{Experimental Trial}

A 15-year-old chestnut (Castanea sativa Mill.) orchard, diagnosed as B deficient by morphological abnormalities and foliar analysis was chosen in 2006 (Portela et al., 2011). A group of 16 trees (Judia variety) was selected for application of the treatments: B0- control and B1- $100 \mathrm{~g}$ per tree of sodium tetraborate (Granubor, Borax Europe Limited, Castéllon, Spain) with $14.6 \%$ $\mathrm{B}$ were broadcast beneath the canopy of eight trees. The 16 trees received a basic fertilization in the winter of 2006/07: dolomitic limestone was used to correct soil acidity and to compensate for the low levels of exchangeable calcium (Ca) and magnesium $(\mathrm{Mg})$ in the soil; mineral fertilizers were used at suitable rates to supply nitrogen $(\mathrm{N})$, phosphorus $(\mathrm{P})$, potassium $(\mathrm{K})$, sulfur $(\mathrm{S})$, zinc $(\mathrm{Zn})$, copper $(\mathrm{Cu})$, and manganese $(\mathrm{Mn})$. Boron fertiliza- 
tion was performed at the beginning of March 2007 and repeated in 2009. Fertilization with macronutrients was repeated at the beginning of 2008 and 2009.

\section{Soil and Plant Sampling, Fruit Parameters, and Laboratory Procedures}

In 2006, composite soil samples representative of the orchard were taken and analyzed for soil fertility parameters. Extractable B was determined in hot water and measured spectrophotometrically by the azomethine $\mathrm{H}$ method (Wolf, 1971). At the end of the experiment (November 2009), sample collection was carried out from the four quadrants beneath the canopy of 10 trees randomly selected (B0 and B1).

Leaf sampling for foliar analysis was carried out in early September, and five trees from each treatment were selected at random. Fully developed leaves of fruiting shoots (fourth to seventh from the terminal shoot), from the external part of middle crown were collected in the four quadrants of the trees and were analyzed for macro- and micronutrients. Leaf samples were dried at $65^{\circ} \mathrm{C}$ for $48 \mathrm{~h}$ and ground to pass through a 1-mm screen. They were digested as described by Van Schouwenburg and Walinga (1978). Calcium, $\mathrm{Mg}, \mathrm{Fe}, \mathrm{Cu}, \mathrm{Zn}$, and Mn were determined by atomic absorption spectrophotometry and $\mathrm{K}$ by flame photometry. For $\mathrm{N}$ and $\mathrm{P}$ analysis, the digestion was with sulfuric acid (Novozamsky et al., 1983) and their concentrations were determined on an autoanalyzer. Boron was measured spectrophotometrically by the azomethine $\mathrm{H}$ method (Wolf, 1971).

In early October 2008 and 2009, fruit setting was evaluated by picking 30-36 burs in the middle crown of the four quadrants of the five trees in shoots uniform in length and exposure, and the percentage of aborted fruits was determined.

Chestnut fruit was harvested from the ground under each of the five trees from B0 and B1. To evaluate nut production, fruits, which passed through a $24 \mathrm{~mm}$ grid, were rejected as unmarketable, and the remainder was weighed in fresh. Samples of 50 nuts were used for determination of dry matter, caliber (nuts $\mathrm{kg}^{-1}$ ), percentage of nuts infested with tortrix (Cydia splendana Hübner) and pericarp (outer shell) cracking. The pericarp plus the pellicle (inner shell), obtained by hand peeling, were weighed and their percentage of the whole fruit was determined. The components of the fruit (shells and kernel) were analyzed for determination of macro- and micronutrients, according to the same methods described earlier for foliar nutrient concentrations. This data allows to calculate the amount of nutrients removed by the whole fruit and to allocate $B$ in the different components of the fruit.

For the purpose of chemical composition of the kernel, samples of shelled chestnut were dried at $65^{\circ} \mathrm{C}$ for $48 \mathrm{~h}$ to determine dry matter and 
analyzed for neutral detergent fiber (NDF) by the method of Robertson and van Soest (1981); crude protein by the micro-Kjeldahl method ( $\mathrm{N}$ total $\mathrm{x}$ 5.3, according to McCarthy and Meredith, 1988); crude fat by extraction with petroleum ether in a Soxhlet apparatus; starch by enzymatic hydrolysis (Salomonsson et al., 1984); soluble sugars were by the colorimetric method of anthrone after extraction with ethanol, as described by Irigoyen et al. (1992).

The data was analyzed by two-way analysis of variance (ANOVA) followed by the Duncan multiple range test $(P<0.05)$ with JMP statistical package (SAS Institute, Cary, NC, USA).

\section{RESULTS}

\section{Climatic Conditions}

Table 1 summarizes some relevant temperature parameters of years 2006-2009, including the accumulation of growing degree-days $\left(\mathrm{D}^{\circ}\right)$ for each year according to Cesaraccio et al. (2001). Table 2 shows the sum of precipitation from November to October (following year) and monthly rainfall from April to October.

Temperature was a serious limiting factor in June-July of 2008 during the pollination period, with the lowest absolute minimum. The average minimum temperature during this period (first week of July 2008) was $9.6^{\circ} \mathrm{C}$ with an absolute minimum of $5.8^{\circ} \mathrm{C}$ (Table 1 ), while the average minimum temperature (average over 30 years, according to INMG, 1991) was $14.1^{\circ} \mathrm{C}$ in the same period. In fact, the parameter degree-days of active growing period (May-October) was much lower in 2008 when compared with 2009 $\left(1921^{\circ} \mathrm{D}\right.$ and $2219^{\circ} \mathrm{D}$, respectively), which influenced the flowering period: full bloom in 2009 occurred two weeks earlier than in 2008.

The total amount of precipitation (Table 2) was not a serious constraint over the years 2006-2009 for chestnut growth but its distribution was. Though the annual precipitation was similar in the three years of the experiment, rainfall was more erratic in 2009; in particular, drought occurred in September, followed by a very rainy October. Both had a dramatic effect on nut productivity and quality, as discussed below.

\section{Foliar and Soil Analysis}

Concentrations of nutrients in chestnut leaves are displayed in Table 3. As expected, none of the nutrients show significant differences between the treatments, except B concentration, with a significant increase when B was supplied (48.4 vs $8.6 \mathrm{mg} \mathrm{kg}^{-1}$ dry weight). In the deficient trees, the variability of foliar B concentration over the three years was narrow $\left(6-10 \mathrm{mg} \mathrm{kg}^{-1}\right)$, while the fertilized ones exhibited larger fluctuation (26-105 $\mathrm{mg} \mathrm{kg}^{-1}$ ). 
TABLE 3 Average foliar nutrient concentrations over three years (2006-2009) in chestnut trees of control (B0) and those fertilized with boron (B1)

\begin{tabular}{|c|c|c|c|c|c|c|c|c|c|c|}
\hline & \multicolumn{5}{|c|}{$\mathrm{g} \mathrm{kg}^{-1}$} & \multicolumn{5}{|c|}{$\mathrm{mg} \mathrm{kg}^{-1}$} \\
\hline & $\mathrm{N}$ & $\mathrm{P}$ & $\mathrm{K}$ & $\mathrm{Ca}$ & $\mathrm{Mg}$ & $\mathrm{Fe}$ & Mn & $\mathrm{Zn}$ & $\mathrm{Cu}$ & B \\
\hline B0 & 21.2 & 1.71 & 8.1 & 9.4 & 1.45 & 54 & 1109 & 28 & 12 & 8.6 \\
\hline B1 & 21.4 & 1.64 & 8.1 & 9.2 & 1.35 & 61 & 1007 & 26 & 13 & 48.4 \\
\hline $\mathrm{P}$ & ns & ns & ns & ns & ns & ns & ns & ns & ns & $* * *$ \\
\hline
\end{tabular}

Liming and fertilization had an evident effect in improving soil fertility parameters, and the increase in extractable B under the B fertilized trees was remarkable $\left(0.44 \mathrm{mg} \mathrm{kg}^{-1}\right.$ in October 2006 to $3.97 \mathrm{mg} \mathrm{kg}^{-1}$ in November 2009).

\section{Nut Production and Nut Quality Parameters}

Table 4 shows the average values and $\mathrm{F}$ test significance level by year and B treatment (main effects) for nut production and some quality parameters, and Table 5 presents the average values of the same parameters by year and treatment (interaction effect). The results displayed in Table 4 show that the $\mathrm{B}$ application was significant for fruit setting and nut productivity. Boron application increased fruit setting $(\mathrm{B} 0=32 \%$ and $\mathrm{B} 1=81 \%)$ and yield $(\mathrm{B} 0$ $=9 \mathrm{~kg}$ tree $^{-1}$ and $\mathrm{B} 1=16 \mathrm{~kg}$ tree $\mathrm{e}^{-1}$ ), but was not statistically significant in the other fruit quality parameters evaluated. With regard to year, all parameters

TABLE 4 Average values of chestnut production, fruit setting and some quality parameters by year and boron treatment and $\mathrm{F}$ test significance of corresponding effect

\begin{tabular}{|c|c|c|c|c|c|c|c|c|}
\hline \multirow[b]{2}{*}{ Parameter } & \multicolumn{4}{|c|}{ Year } & \multicolumn{3}{|c|}{ Treatment } & \multirow{2}{*}{$\begin{array}{c}\text { Interaction } \\
\text { Signific. }\end{array}$} \\
\hline & 2007 & 2008 & 2009 & Signific. & B0 & B1 & Signific. & \\
\hline $\begin{array}{l}\text { Fruit } \\
\quad \text { setting,\% }\end{array}$ & - & 50 & 63 & $*$ & $32 \mathrm{a}$ & $81 b$ & $* * *$ & $*$ \\
\hline $\begin{array}{l}\text { Yield, } \\
\text { kg/tree }\end{array}$ & 12 & 12 & 14 & ns & $9 \mathrm{a}$ & $16 \mathrm{~b}$ & $* *$ & ns \\
\hline $\begin{array}{l}\text { Caliber, } \\
\text { fruits } / \mathrm{kg}\end{array}$ & $61 \mathrm{a}$ & $80 \mathrm{~b}$ & $119 \mathrm{c}$ & $* * *$ & 83 & 91 & ns & ns \\
\hline $\begin{array}{l}\text { Tortrix } \\
\text { infesta- } \\
\text { tion, } \%\end{array}$ & $1.0 \mathrm{a}$ & $4.2 \mathrm{~b}$ & $2.9 \mathrm{ab}$ & $* *$ & 3.5 & 1.9 & ns & ns \\
\hline $\begin{array}{l}\text { Shell crack- } \\
\text { ing, } \%\end{array}$ & $0.6 \mathrm{a}$ & $15 \mathrm{a}$ & $93 \mathrm{~b}$ & $* * *$ & 39 & 32 & ns & ns \\
\hline $\begin{array}{l}\text { Dry } \\
\quad \text { matter, } \%\end{array}$ & $57 \mathrm{~b}$ & $59 \mathrm{~b}$ & $52 \mathrm{a}$ & $* *$ & 55 & 56 & ns & ns \\
\hline
\end{tabular}

For the year and treatment, means in the same line with a common letter are not significantly different. *,**,*** Significant at $P<0.05, P<0.01$, and $P<0.001$, respectively. 
TABLE 5 Chestnut production, fruit setting and some quality parameters

\begin{tabular}{|c|c|c|c|c|c|c|}
\hline 2007 & $\begin{array}{c}\text { Fruit } \\
\text { setting,\% }\end{array}$ & $\begin{array}{c}\text { Yield } \\
\mathrm{kg} \text { tree }^{-1}\end{array}$ & $\begin{array}{c}\text { Caliber } \\
\text { nuts kg }{ }^{-1}\end{array}$ & $\begin{array}{c}\text { Dry } \\
\text { matter, } \%\end{array}$ & $\begin{array}{c}\text { Tortrix } \\
\text { infestation, \% }\end{array}$ & $\begin{array}{c}\text { Shell } \\
\text { cracking,\% }\end{array}$ \\
\hline B0 & - & $8 \mathrm{a}$ & $63 \mathrm{a}$ & $57 \mathrm{a}$ & $1.6 \mathrm{a}$ & $0 \mathrm{a}$ \\
\hline B1 & - & $14 \mathrm{~b}$ & $64 \mathrm{a}$ & $57 \mathrm{a}$ & $0.4 \mathrm{a}$ & $1 \mathrm{a}$ \\
\hline \multicolumn{7}{|l|}{2008} \\
\hline $\mathrm{B} 0$ & $19 \mathrm{a}$ & $4 \mathrm{a}$ & $74 \mathrm{a}$ & $58 \mathrm{a}$ & $5.6 \mathrm{a}$ & $16 \mathrm{a}$ \\
\hline B1 & $80 \mathrm{~b}$ & $17 \mathrm{~b}$ & $86 \mathrm{a}$ & $59 \mathrm{a}$ & $2.8 \mathrm{a}$ & $7 \mathrm{a}$ \\
\hline \multicolumn{7}{|l|}{2009} \\
\hline B0 & $45 \mathrm{a}$ & $13 \mathrm{a}$ & $109 \mathrm{a}$ & $51 \mathrm{a}$ & $4.5 \mathrm{a}$ & $94 \mathrm{a}$ \\
\hline B1 & $82 \mathrm{~b}$ & $15 \mathrm{a}$ & $128 \mathrm{a}$ & $53 \mathrm{a}$ & $1.3 \mathrm{a}$ & $92 \mathrm{a}$ \\
\hline
\end{tabular}

Means in the same column and year with a different letter are significantly different $(P<0.05)$ by the Duncan multiple range test.

but yield showed significant differences, reflecting the variation in weather conditions over the three years.

The average fruit setting was constant in B fertilized trees (about 80\%) while in $\mathrm{B} 0$ there was variation according to year. In fact the percentage of fruit setting was very low in 2008 in B deficient trees (19\%) when compared with $45 \%$ in 2009 (Table 5).

While B fertilization significantly improved nut production in 2007 and 2008, there was no significant increase in nut production in 2009 between B0 and B1. In 2009, the slight difference in fruit production between treatments might be ascribed to two facts: less fruit abortion in B0 in 2009 and the small size of fruits in B1. In this treatment many fruits were considered unmarketable $(\varnothing<24 \mathrm{~mm})$ and therefore rejected, while in $\mathrm{B} 0$ fruit abortion resulted in bigger fruits. Thus, nut production was reduced by $61 \%$ in $\mathrm{B} 1$, but only $33 \%$ in B0, otherwise nut production would have been higher and the difference greater (B1- $35 \mathrm{~kg}$ tree $^{-1}$ and B0- $18 \mathrm{~kg}$ tree $^{-1}$ ).

As shown in Table 4, no significant differences were observed in quality parameters such as caliber, dry matter, shell cracking, and tortrix infestation

TABLE 6 Chemical composition $(\mathrm{dw})$ of the kernel. F test significance between years and boron treatment

\begin{tabular}{|c|c|c|c|c|c|c|c|c|}
\hline \multirow[b]{2}{*}{ Parameter } & \multicolumn{4}{|c|}{ Year } & \multicolumn{3}{|c|}{ Treatment } & \multirow{2}{*}{$\begin{array}{c}\text { Interaction } \\
\text { signific. }\end{array}$} \\
\hline & 2007 & 2008 & 2009 & Signific. & B0 & $\mathrm{B} 1$ & Signific. & \\
\hline Dry matter, $\%$ & $57 \mathrm{c}$ & $54 \mathrm{~b}$ & $51 \mathrm{a}$ & $* * *$ & $53 \mathrm{a}$ & $54 \mathrm{~b}$ & ns & $*$ \\
\hline Starch, $\%$ & $54 \mathrm{~b}$ & $49 \mathrm{a}$ & $61 \mathrm{c}$ & $* * *$ & 55 & 55 & ns & ns \\
\hline Soluble sugars, $\%$ & $18 \mathrm{c}$ & $15 \mathrm{~b}$ & $8 \mathrm{a}$ & $* * *$ & 13 & 14 & ns & ns \\
\hline Total fiber NDF,\% & $20 \mathrm{~b}$ & $16 \mathrm{a}$ & $16 \mathrm{a}$ & $* * *$ & 17 & 17 & ns & $*$ \\
\hline Crude protein, $\%$ & $5.5 \mathrm{a}$ & $5.3 \mathrm{a}$ & $6.2 \mathrm{~b}$ & $* *$ & 5.5 & 5.8 & ns & * \\
\hline Crude fat, $\%$ & $1.1 \mathrm{a}$ & $2.4 \mathrm{~b}$ & $2.7 \mathrm{~b}$ & $* * *$ & $1.9 \mathrm{a}$ & $2.3 \mathrm{~b}$ & $* *$ & * \\
\hline
\end{tabular}

For the year and treatment, means in the same line with a common letter are not significantly different. 
TABLE 7 Nutrient concentration of the kernel, referred to dry weight

\begin{tabular}{|c|c|c|c|c|c|c|c|c|}
\hline \multirow[b]{2}{*}{ Nutrient } & \multicolumn{4}{|c|}{ Year } & \multicolumn{3}{|c|}{ Treatment } & \multirow{2}{*}{$\begin{array}{c}\text { Interaction } \\
\text { signific. }\end{array}$} \\
\hline & 2007 & 2008 & 2009 & Signific. & $\mathrm{B} 0$ & B1 & Signific. & \\
\hline $\mathrm{N}, \mathrm{g} \mathrm{kg}^{-1}$ & $8.2 \mathrm{a}$ & $8.6 \mathrm{a}$ & $10.4 \mathrm{~b}$ & $* *$ & 8.9 & 9.4 & $\mathrm{~ns}$ & $\mathrm{~ns}$ \\
\hline $\mathrm{P}, \mathrm{g} \mathrm{kg}^{-1}$ & $1.13 \mathrm{~b}$ & $0.97 \mathrm{a}$ & $0.88 \mathrm{a}$ & $* * *$ & 1.00 & 0.98 & ns & ns \\
\hline $\mathrm{K}, \mathrm{g} \mathrm{kg}^{-1}$ & $10.3 \mathrm{~b}$ & $9.2 \mathrm{~b}$ & $7.1 \mathrm{a}$ & $* * *$ & 8.8 & 8.8 & ns & $*$ \\
\hline $\mathrm{Ca}, \mathrm{g} \mathrm{kg}^{-1}$ & $0.20 \mathrm{a}$ & $0.60 \mathrm{~b}$ & $0.70 \mathrm{~b}$ & $* *$ & 0.55 & 0.48 & ns & ns \\
\hline $\mathrm{Mg}, \mathrm{g} \mathrm{kg}^{-1}$ & $0.73 \mathrm{a}$ & $1.98 \mathrm{~b}$ & $0.63 \mathrm{a}$ & $* * *$ & 1.13 & 1.12 & ns & ns \\
\hline $\mathrm{Fe}, \mathrm{mg} \mathrm{kg}^{-1}$ & $21 \mathrm{~b}$ & $13 \mathrm{a}$ & $31 \mathrm{c}$ & $* * *$ & 20 & 23 & ns & ns \\
\hline $\mathrm{Mn}, \mathrm{mg} \mathrm{kg}^{-1}$ & $48 \mathrm{~b}$ & $33 \mathrm{a}$ & $46 \mathrm{~b}$ & $*$ & 42 & 42 & ns & ns \\
\hline $\mathrm{Zn}, \mathrm{mg} \mathrm{kg}^{-1}$ & $6 \mathrm{a}$ & $20 \mathrm{c}$ & $11 \mathrm{~b}$ & $* * *$ & 13 & 13 & ns & ns \\
\hline $\mathrm{Cu}, \mathrm{mg} \mathrm{kg}^{-1}$ & $4.6 \mathrm{a}$ & $5.6 \mathrm{a}$ & $13.6 \mathrm{~b}$ & $* * *$ & 8.3 & 7.6 & ns & ns \\
\hline $\mathrm{B}, \mathrm{mg} \mathrm{kg}^{-1}$ & $9.4 \mathrm{c}$ & $7.7 \mathrm{~b}$ & $4.0 \mathrm{a}$ & $* * *$ & $4.2 \mathrm{a}$ & $9.5 \mathrm{~b}$ & $* * *$ & $* *$ \\
\hline
\end{tabular}

For the year and treatment, means in the same line with a common letter are not significantly different.

as a result of $\mathrm{B}$ fertilization. However, the year had a dramatic effect on all fruit parameters. In 2009, small nut size is evidenced by the poor caliber (119 fruits $\mathrm{kg}^{-1}$ ), when compared with previous years (61 and 80 fruits $\mathrm{kg}^{-1}$ in 2007 and 2008, respectively). Tortrix infestation was absent in 2007 and almost irrelevant in the following years. Shell cracking was very high in 2009, with more than $90 \%$ of nuts having fissured shells, and the percentage of dry matter was lower.

Table 6 displays the composition of the chestnut kernel according to year and treatment and $\mathrm{F}$ test significance level. The variation in chemical composition was much influenced by year, rather than by $\mathrm{B}$ fertilization. However B application increased the content of crude fat from $1.9 \%$ to $2.3 \%$, while the other parameters were not significantly affected. There was an increase in crude fat from 2007 to 2009; and a value of $3 \%$ of crude fat was reached in 2008 and 2009 if B was applied.

Table 7 reveals that nutrient concentration in the kernel was affected by year and B treatment. As expected, B application led to an obvious and significant increase in B concentration. However, there was a significant decrease in B concentration in the kernel from 2007 to 2009. In 2009, regardless of $\mathrm{B}$ application, a very low concentration of $\mathrm{B}$ was observed

TABLE 8 Average nutrient concentration in fruit components (2007-2009) and amount of B extracted per $\mathrm{kg}$ of the whole fruit, both expressed in dry weight and fresh in B1 treatment

\begin{tabular}{lccc}
\hline $\begin{array}{l}\text { B concentration, } \\
\mathrm{mg} \mathrm{kg}^{-1}\end{array}$ & Amount of B extracted, $\mathrm{mg} \mathrm{kg}^{-1}$ of fruit \\
\hline Pericarp+pellicle & Kernel & Fruit dry weight* & Fresh fruit \\
21.2 & 9.5 & 12.2 & 6.8 \\
\hline
\end{tabular}

\footnotetext{
*- Kernel represents $77 \%$, and pericarp+pellicle $23 \%$ of the whole fruit dry weight.

+ The dry weight represented in average $56 \%$ of the whole fresh fruit.
} 
(2.8 $\mathrm{mg} \mathrm{kg}^{-1}$ and $5.2 \mathrm{mg} \mathrm{kg}^{-1}$ respectively in B0 and B1) when compared with previous years.

In Table 8 both the average concentration of B in the shells (pericarp plus pellicle) and kernel, and the amount extracted for each $\mathrm{kg}$ of fruit [dry weight $(\mathrm{dw})$ and fresh] under B fertilization are summarized. Boron concentration in the shells is more than twice as high as in the kernel. Though shells are a minor part of the whole fruit $(23 \%)$, they account for half of the fruit export.

It can be calculated that the output of B for each ton of fresh chestnut exported is about $7 \mathrm{~g} \mathrm{t}^{-1}$ of $\mathrm{B}$. This can be a useful indicator to predict $\mathrm{B}$ output from fruit harvesting. However, the output of B for the whole fruit is not large, and is of the same magnitude as $\mathrm{Zn}$ removal from fruit, according to the data of Pires and Portela (2009).

\section{DISCUSSION}

Results suggest that chestnut productivity, several quality parameters, and chemical composition of chestnuts are very much influenced by year, which reinforces the importance of climatic conditions on chestnut behavior and nut quality (Pereira et al., 2011; Dinis et al., 2011a, 2011b; Ferreira-Cardoso, 2007).

Although establishing of the relation between weather conditions and chestnut productivity and quality parameters is not a simple task, due to several factors, some papers highlight its importance (Heiniger and Conedera, 1992; Fernández-López et al., 2005; Bounous, 2002). For the specific conditions of Portugal, Gomes-Laranjo (2006), Pereira et al. (2011) and Dinis et al. (2011a) identify some temperature and precipitation predictors, namely mean air temperature from January to March, maximum air temperature in January, July, and September, and the accumulated precipitation of April, May, and September as climatic variables with a high correlation and impact on chestnut production and fruit quality. The results obtained in this experiment seem to corroborate the selection of meteorological parameters by Pereira et al. (2011), such as the accumulated rainfall of April, July, and September for a prediction model to simulate chestnut productivity.

Paradoxically, in this trial, there was no influence of year on nut productivity. However this can be explained by the decision taken beforehand to reject small nuts $(\varnothing<24 \mathrm{~mm})$. Otherwise, production in 2009 would be much greater than in previous years, as mentioned above. For the same reason, there was no significant increase in nut production in 2009 due to $B$ fertilization, but it significantly improved nut production in 2007 and 2008. The dry September of 2009 (Table 2) resulted in small fruits, particularly in B1, while in B0 nut abortion enhanced fruit growth $(\varnothing>24 \mathrm{~mm})$. These two occurrences levelled off nut productivity between $\mathrm{B} 0$ and $\mathrm{B} 1$. The formation 
of larger fruits under B deficiency is often observed and is explained by Dell and Huang (1997), who observed that where the demand for B cannot be met some fruits abort, and those that can acquire enough B for growth may benefit from the reduced competition for assimilates by forming larger fruits. Indeed, under drought, this might compensate for the loss in quantity.

Climatic conditions were also responsible for a dramatic effect on some quality parameters (Table 5), particularly in caliber (119 fruits $\mathrm{kg}^{-1}$ ) and shell cracking (>90\%), which were ruinous in 2009. A dry September was followed by a rainy October, which led to kernel swelling and cracking of shells. This is a very undesirable characteristic, which is sometimes occasioned promoted by the first rains of October after a very dry spell (FerreiraCardoso, 2007). Because desiccation of either the pellicle or the pericarp has already been initiated, delayed precipitation causes further growth of the cotyledons, inducing the rupture of the shells, which becomes a serious defect, whose main consequence is the negative impact on conservation capacity of chestnuts.

The high number of aborted fruits in 2008 was ascribed to the cold temperatures (Table 1) that occurred during the flowering period (June-July), with an absolute minimum of $5.8^{\circ} \mathrm{C}$ on the 7 th of July, which probably induced failure in setting fruit and enhanced the response to $\mathrm{B}$ application, when compared with 2009. It is worth noting that the cumulative degree-days value calculated in $2008\left(1921^{\circ} \mathrm{D}\right)$ is somewhat lower than that determined for 2007 , and much lower than $2009\left(2008^{\circ} \mathrm{D}\right.$ and $2219^{\circ} \mathrm{D}$ respectively). These data seem to corroborate the usefulness of the parameter degree-days (May-October) for describing the biological development of chestnut and the occurrence of fruit abortion (Dinis et al., 2011a). Gomes-Laranjo et al. (2009) also recorded increased fruit abortion as temperatures diminish with increasing altitude.

The coincidence of cold episodes with the occurrence of B deficiency during reproductive development is known to cause crop failure in several plant species, due to lack of fruit/seed setting (Dell and Huang, 1997; Subedi et al., 1998). The same authors also recognize the role of B during the flowering process and in enhancing tolerance to low temperatures.

In 2008, in this orchard, Portela and Louzada (2012) observed B mobilization to the reproductive organ of chestnut in trees in $\mathrm{B} 0$, but not in B1. In July, while B concentration in leaves was $8.8 \mathrm{mg} \mathrm{kg}^{-1}$, the B level in the flowers was $13.6 \mathrm{mg} \mathrm{kg}^{-1}$, although it was not high enough to prevent fruit abortion. Indeed, in B1 treatment, concentration in flowers was higher $\left(18 \mathrm{mg} \mathrm{kg}^{-1}\right)$.

It is speculated that the lack of rainfall in September 2009 caused a lower B concentration in the kernel, in spite of the soil being well provided with B. It is very likely that the low soil water content depressed B uptake and its mobilization to the fruit. It is worth noting that B was applied to the soil in March of both 2007 and 2009. Thus, B was plentiful in the soil (about 
$4 \mathrm{mg} \mathrm{kg}^{-1}$ ) in B1. Although foliar concentration was high in the beginning of September $\left(62 \mathrm{mg} \mathrm{kg}^{-1}\right)$, B concentration in the kernel of B1 was only $5.2 \mathrm{mg} \mathrm{kg}^{-1}$, which was far below the level of previous years $\left(13.1 \mathrm{mg} \mathrm{kg}^{-1}\right.$ and $10.2 \mathrm{mg} \mathrm{kg}^{-1}$ in 2007 and 2008 respectively). Therefore, no retranslocation of $\mathrm{B}$ had occurred from the leaves to the fruit. This means that $\mathrm{B}$ mobilization to the fruit was more dependent on external supply than on internal retranslocation, or that $B$ retranslocation from leaves to the fruit was restricted under water stress. It is plausible that the combination of high temperatures and lack of rainfall in September 2009 (Table 1 and Table 2) was the limiting factor to B uptake and mobilization to the fruit. It has long been recognized that water flux from the soil and transpiration are the driving forces for B uptake, and that B deficiencies in many crops are associated with hot dry weather (Shorrocks, 1997). The particular site conditions of this orchard such as the shallowness of the soil and the abundance of rock fragments have certainly contributed to low water supply from the soil.

Chestnut has a lower concentration of B in the kernel compared with the shells (Table 7 and 8), in such a way that the amount exported by the fruit can be equally allocated to the shells and to the kernel. In other nut trees, such as walnut and pistachio, Brown and Shelp (1997) record the same pattern of $\mathbf{B}$ distribution as was found for chestnut. These workers interpret this as indicative of limited B mobility in the phloem of these species.

Crude fat in kernel was low in the control trees, and only reached values of $3 \%$ with B fertilization. Similar values were obtained in some other European regions, such as Galicia (De La Montaña et al., 1997) and in Turkey (Üstün et al., 1999), but higher values were recorded by Desmaison and Adrian (1986) in French chestnuts (3.6\%) and by Bounous et al. (1988) in the Italian ones (within the range of 2.2-3.4\%). The value of crude fat surveyed over four years by Ferreira-Cardoso (2007) in several varieties in the northeast (NE) region was in general low and close to the average value obtained in B0 of the present study. More recent studies (Dinis et al., 2011b), conducted in the same region, show that higher contents of crude fat are associated with warmer years and warmer localities (both assessed in terms of degree-days). Portela et al. (1999) show that magnesium deficiency significantly reduces crude fat in chestnuts, which may be as low as $<1 \%$ in the kernel of trees with severe magnesium deficiency. Thus, it is still to be determined whether or not the low values of crude fat in chestnut is related more to climatic conditions or to the low levels of B occurring in some soils, or both.

The effect of B fertilization on the increase of fat content was also observed by Mondy et al. (2006) in three varieties of potato grown with and without $B$ foliar spray. In addition, according to this study, the treatment of potatoes with $B$ tended to increase the amount of unsaturated, and decrease the amount of saturated fatty acids. This fact may be of great importance to the health of consumers, and will be an interesting subject in future research on chestnut fruit. 
Cold temperatures are not usually expected to be a stress factor during the reproductive development of chestnut in major chestnut growing areas of NE region. However, at high altitudes, cold spells may occur. The recent establishment of new orchards at increasing altitudes (Gomes-Laranjo et al., 2009) may lead to more frequent cold episodes in the flowering period, and it is to be expected that failure of nut setting will be more frequent. Interaction between climate and B nutrition is suggested by systematic observations in chestnut orchards (Portela and Sismeiros, 2011). Therefore, there is a need to pinpoint the susceptible stages of the chestnut growing cycle, so that precautions and corrective actions can be taken with respect to cultural practices, particularly the timing of B application, as already suggested by Portela and Louzada (2012).

\section{CONCLUSIONS}

The effect of boron on chestnut productivity and nut quality depends, to a great extent, upon climatic conditions. Boron fertilization may increase nut setting more than two-fold. Its beneficial effect varies according to mean air temperature during the flowering period (June-July) and is greater as the temperature falls. As a consequence of increased fruit setting, nut yield increases, but caliber may diminish, being more accentuated under water stress (as happened in 2009). A dry summer may have an adverse effect on nut productivity, because fruits may be too small and with reduced economic value. Results also show that adequate boron nutrition may improve the crude fat content of the kernel.

\section{ACKNOWLEDGMENTS}

Field assistance was provided by José Rego. Chemical analyses were carried out in the Laboratory of Applied Biology and Laboratory of Soils and Plants of the University of Trás-os-Montes and Alto Douro.

\section{FUNDING}

This study was supported by grants from CITAB.

\section{REFERENCES}

Bounous, G. 2002. Il Castagno: Coltura, Ambiente ed Utilizzazione in Italia e Nel Mondo [The chestnut: crop management, environment and use in Italy and in the world]. Bologna, Italy: Edicione Agricole.

Bounous, G., N. Agnisetta, M. C. Baldizzone, D. Gioffré, R. Paglietta, and R. Zappia. 1988. Indagine sulle caratteristiche bioagronomiche di 10 cultivar di castagno piemontesi [Survey on bio-agronomic characteristics of 10 chestnut cultivars of Piedmont]. L'Informatore Agrario 49: 51-57.

Brown, P. H., and B. J. Shelp. 1997. Boron mobility in plants. Plant and Soil 193: 85-101. 
Cesaraccio, C., D. Spano, P. Duce, and R. L. Snyder. 2001. An improved model for determining degree-day values from daily temperature data. International Journal of Biometeorology 45: 161-169.

De La Montaña, J., J. M. García, and M. Miguez. 1997. Composicion nutricional de determinadas variedades de castañas en la comarca de Monterrei (SE Orense) [Nutritional composition of several sweet chestnut varieties in Monterrei county (SE Orense)]. Alimentaria, Enero-Febrero: 19-22.

Dell, B., and L. Huang. 1997. Physiological response of plants to low boron. Plant and Soil 193: 103-120.

Desmaison, A. M., and J. Adrian. 1986. La place de la châtaigne en alimentation [Role of sweet chestnut in nutrition]. Médicine et Nutrition 22: 174-180.

Dinis, L. T., F. Peixoto, T. Pinto, R. Costa, J. Bennett, and J. Gomes-Laranjo. 2011a. Study of morphological and phenological diversity in chestnut trees ('Judia' variety) as a function of temperature sum. Environmental and Experimental Botany 70: 110-120.

Dinis, L. T., J. Ferreira-Cardoso, F. Peixoto, R. Costa, and J. Gomes-Laranjo. 2011b. Study of morphological and chemical diversity in chestnut trees (var. 'Judia') as a function of temperture sum. CyTA-Journal of Food 9: 192-199.

FAO. 2006. World Reference Base for Soil Resources. World Soil Resources Reports No 103. Rome: FAO.

Fernández-López, J., R. Zas, R. Diaz, F. Villani, M. Cherubini, F. A. Aravanopoulos, G. Alizoti, G. Eriksson, R. Botta, and M. G. Mellano. 2005. Geographic variability among extreme European wild chestnut populations. Acta Horticulturae 693: 181-186.

Ferreira-Cardoso, J. 2007. Valorização da castanha Portuguesa. Características tecnológicas e nutricionais [Increasing the commercial value of Portuguese chestnut: technological characteristics and nutritional value]. In: Castanheiros, [Chestnuts], eds J. Gomes-Laranjo, J. Ferreira-Cardoso, E. Portela, and C.G. Abreu, pp. 281-348. Vila Real, Portugal: Programa AGRO 499, Universidade de Trás-os-Montes e Alto Douro.

Gomes-Laranjo, J. 2006. Study of the temperature effect in three chestnut (Castanea sativa Mill.) cultivars' behaviour. Journal of Plant Physiology 163: 945-955.

Gomes-Laranjo, J., P. Almeida, A. G. Luzio, J. Ferreira-Cardoso, and F. Peixoto. 2009. Ecophysiological characterization of C. sativa trees growing under different altitudes. Acta Horticulturae 844: 119-126.

Heiniger, U., and M. Conedera. 1992. Chestnut forests and chestnut cultivation in Switzerland. In: Proceedings of the International Chestnut Conference, ed. W. L. Double, pp. 175-178. Morgantown, WV: West Virginia University.

Huang, L., Y. Zhengoian, R. W. Bell, and B. Dell. 2005. Boron nutrition and chilling tolerance of warm climate crop species. Annals of Botany 96: 755-767.

INMG. 1991. Clima de Portugal [Portugal's Climate]. Instituto Nacional de Meteorologia e Geofísica Vol. 3, number 49. Lisbon: Instituto Nacional de Meteorologia e Geofísica.

Irigoyen, J. J., D. W. Emerich, and M. Sánchez-Díaz. 1992. Water stress induced changes in concentrations of proline and total soluble sugars in nodulated alfalfa (Medicago sativa) plants. Physiologia Plantarum 84: 55-60.

McCarthy, M. A., and F. I. Meredith. 1988. Nutrient data on chestnuts consumed in the United States. Economic Botany 42: 29-36.

Mondy, N. I., A. Bourque, B. Breslow, and L. R. Mattick. 2006. The effect of boron on the lipid content and discoloration of potatoes. Journal of Food Science 30: 420-425.

Novozamsky, I., V. J. G. Houba, R. van Eck, and W. van Vark. 1983. A novel digestion technique for multi-element plant analysis. Communications in Soil Science and Plant Analysis 14: 239-249.

Pereira, M. G., L. Caramelo, C. Gouveia, J. Gomes-Laranjo, and M. Magalhães. 2011. Assessment of weather-related risk on chestnut productivity. Natural Hazards and Earth System Sciences 11: 2729-2739.

Pires, A. L., and E. Portela. 2009. Assessment of nutrient outputs in chestnut groves: Fruit and pruned biomass. Acta Horticulturae 815: 75-81.

Portela, E., J. Ferreira-Cardoso, and J. Louzada. 2011. Boron application on a chestnut orchard. Effect on yield and quality of nuts. Journal of Plant Nutrition 34: 1245-1253.

Portela, E., J. Ferreira-Cardoso, J. M. Roboredo, and M. Pimentel-Pereira. 1999. Influence of magnesium deficiency on chestnut (Castanea sativa Mill.) yield and quality. In: Improved Crop Quality by Nutrient Management, eds. D. Anaç and P. Martin-Prével, pp. 153-158. Dordrecht, the Netherlands: Kluwer Academic Publishers.

Portela, E., and J. Louzada. 2012. Early diagnosis of boron deficiency in chestnut. Journal of Plant Nutrition 35: 304-310. 
Portela, E., A. Martins, A. L. Pires, F. Raimundo, and G. Marques. 2007. Cap 6 - Práticas culturais no souto: o manejo do solo. [Soil management practices in chestnut orchards]. In: Castanheiros, [Chestnuts], eds J. Gomes-Laranjo, J. Ferreira-Cardoso, E. Portela, and C.G. Abreu, pp. 207-264. Vila Real, Portugal: Programa AGRO 499, Universidade de Trás-os-Montes e Alto Douro.

Portela, E., and R. Sismeiros, R. 2011. Morte súbita do castanheiro: geada ou deficiência de boro? [Sudden death of chestnuts: frost or boron deficiency?]. Frutas, Legumes e Flores 117: 58-62.

Robertson, J. B., and P. J. Van Soest. 1981. The detergent system of analysis and its application to human foods. In: The Analysis of Dietary Fiber in Food, eds. W. P. T. James, and O. Theander, pp. 123-158. New York: Marcel Dekker.

Salomonsson, A., A. Theander, and E. Westerlund. 1984. Chemical characterisation of some cereal whole meal and bran fractions. Swedish Journal of Agricultural Research 14: 111-117.

Shorrocks, V. M. 1997. The occurrence and correction of boron deficiency. Plant and Soil 193: 121-148.

Subedi, K. D., P. J. Gregory, R. J. Summerfield, and M. J. Gooding. 1998. Cold temperatures and boron deficiency caused grain set failure in spring wheat (Triticum aestivum L.). Field Crop Research 57: 277-288.

Üstün, N., Y. Tosun, and Ü. Serdar. 1999. Technological properties of chestnut varieties grown in Erfelek district of Sinop city. Acta Horticulturae 494: 107-110.

Van Schouwenburg, J. C., and I. Walinga. 1978. Methods of analysis for plant material. Dordrecht, the Netherlands: Agricultural University of Wageningen.

Wolf, B. 1971. The determination of boron in soil extracts, plant materials composts, manures, water and nutrient solutions. Communications in Soil Science and Plant Analysis 2: 363-37. 